\title{
Bioremoval of Heavy Metals from Effluent of Port Harcourt Refinery Using Pluerotus ostreatus
}

\section{Stanley $\mathbf{H O}^{1 *}$, Ihennacho $\mathbf{C M}^{1}$ and Stanley $\mathbf{C N}^{2}$}

${ }^{1}$ Department of Microbiology, Faculty of Biological Sciences, University of Port Harcourt, P. M. B. 5323, Port Harcourt, Rivers State, Nigeria ${ }^{2}$ Department of Pharmaceutical Microbiology and Biotechnology, Faculty of Pharmaceutical Sciences, University of Port Harcourt, P.M.B.5323, Port Harcourt, Rivers State, Nigeria

\begin{abstract}
The presence of heavy metals in refinery effluent has the potential to pose significant risks to human health and the environment. However, the conventional heavy metal removal has limitations hence the need to introduce alternative treatments. Recently, there have been considerable interests in bio-adsorption of heavy metal using fungus. In the present study, the effectiveness of iron, zinc, lead, nickel, cadmium and chromium removal from refinery effluent was evaluated using living white rot fungus (spawn) viz., Pleurotus ostreatus. The fungus was amended with sawdust and rice bran. Physiochemical analysis of the effluent on day zero indicated the presence of Iron $(0.775 \mathrm{mg} / \mathrm{L})$, Zinc $(0.750 \mathrm{mg} / \mathrm{L})$, Lead $(0.031 \mathrm{mg} / \mathrm{L})$, Nickel $(0.188 \mathrm{mg} / \mathrm{L})$, Chromium $(0.025 \mathrm{mg} / \mathrm{L})$ and Cadmium $(0.054 \mathrm{mg} / \mathrm{L})$. P. ostreatus bioremoved the metals under study at $\mathrm{pH} 7.6$, Temperature at $26.8^{\circ} \mathrm{C}$ and contact time 60 days with substrate (sawdust mixed with rice bran). Throughout the research, the percentage of removal was found to increase with increasing contact time. The heavy metals were determined using an atomic absorption spectrophotometer. Sawdust mixed with rice bran colonized with $P$. ostreatus spawn could be utilized as an excellent biosorbent thus exhibiting efficiency for Iron 80\%, Zinc 99\%, Lead 94\%, Nickel 99\%. Chromium 93\%, and Cadmium $96 \%$ respectively. The analysis of variance of the five variables: lead, iron, nickel, cadmium and chromium showed that there was no significant difference at $\mathrm{P}<0.05$ with the exception of iron. It was observed that $P$. ostreatus is efficient in bioremoving heavy metals as the levels of remaining heavy metals in the refinery effluent were below the limit of detection $(<0.001 \mathrm{mg} / \mathrm{L})$. This validates $P$. ostreatus as a potential bio-sorbent and can be employed in treatment of environments polluted with effluent containing high levels of lead, zinc, iron, nickel, cadmium and chromium.
\end{abstract}

Keywords: Pleurotus ostreatus; Effluent; Bioadsorption; Heavy metals

\section{Introduction}

Studies on heavy metals removal from liquid waste had been launched due to ecological effects of toxic metal release into the environment [1]. Metal laden industrial waste waters are hazardous liquid wastes which have adverse implications for public health as well as surrounding ecological systems since metals are generally nonbiodegradable and can bio-accumulate in living tissues. Over the past decades, the influx of these metals laden waste waters into the earth surface and environment has increased significantly due to large scale global industrialization. These toxic metals include zinc, nickel, iron, chromium, lead and cadmium which originate from industries.

Heavy metal removal from industrial waste water has been practiced for several decades. The conventional physicochemical methods such as chemical precipitation, chemical oxidation or reduction, electrochemical treatment, evaporative recovery, filtration, ion exchange, and membrane technologies have been widely used to remove heavy metal ions from industrial waste water. These processes may be ineffective or expensive and have short comings such as incomplete removal of metals, limited tolerance to $\mathrm{pH}$ change, production of toxic sludge or other products that also need disposal, especially when the heavy metal ions are in solutions with concentrations between 1-100 mg dissolved heavy metal ions/L by Wang and Chen in 2009. Biological methods such as bioremoval of heavy metal ions may provide an attractive alternative to physicochemical methods. Recently, heavy metal ions removal from industrial waste water was difficult due to implementation of more stringent laws and regulations that control the concentrations of pollutants in effluents discharged into water and soils at levels lower than $1 \mathrm{mg} / \mathrm{kg}$ [2]. Traditional methods of metal ions removal became inefficient in the removal of metal ions below this concentration. Therefore, there was need to search for other methods that would be efficient at low concentration of pollutants. Bioremoval, an alternative method of treatment provided this possibility. Bioremoval can therefore be defined as the ability of biological materials to accumulate or concentrate heavy metals through metabolically mediated or physiochemical pathways of uptake [3].

The search for new technologies involving the removal of toxic metals from wastewaters has directed attention to bioremoval, a method based on metal binding capacities of various biological materials. The major advantages of bioremoval over conventional methods of treatment in that the processes does not produce chemical or biological sludge hence no secondary pollution and does not require additional nutrient. It's an effective and easy treatment option. It also involves the regeneration of biosorbents and possibility of heavy metals recovery. The cost is so much less, because the biosorbents used are often waste from farms or they are very easy to regenerate, as is the case with $P$. ostreatus and another harvested biomass.

In vivo research has shown that consumption of oyster mushrooms

"Corresponding author: Stanley HO, Department of Microbiology, Faculty of Biological Sciences, University of Port Harcourt, P. M. B. 5323, Port Harcourt, Rivers State, Nigeria, Tel: +234 84817 941; E-mail: okehstanley@yahoo.com

Received April 07, 2017; Accepted April 20, 2017; Published April 25, 2017

Citation: Stanley HO, Ihennacho CM, Stanley CN (2017) Bioremoval of Heavy Metals from Effluent of Port Harcourt Refinery Using Pluerotus ostreatus. J Pet Environ Biotechnol 7: 324. doi: 10.4172/2157-7463.1000324

Copyright: (c) 2017 Stanley HO, et al. This is an open-access article distributed under the terms of the Creative Commons Attribution License, which permits unrestricted use, distribution, and reproduction in any medium, provided the original author and source are credited. 
Citation: Stanley HO, Ihennacho CM, Stanley CN (2017) Bioremoval of Heavy Metals from Effluent of Port Harcourt Refinery Using Pluerotus ostreatus. J Pet Environ Biotechnol 7: 324. doi: 10.4172/2157-7463.1000324

\begin{tabular}{|c|c|c|c|}
\hline Parameters & Effluent & Filtered Effluent & $\begin{array}{l}\text { DPR Maximum } \\
\text { Permissible Limit }\end{array}$ \\
\hline $\mathrm{PH}$ & 6.87 & 7.05 & $6.5-8.5$ \\
\hline Temp, $\left({ }^{\circ} \mathrm{C}\right)$ & 27.10 & 26.90 & 25 \\
\hline $\begin{array}{l}\text { Total Dissolved Solids, } \\
\text { (mg/L) }\end{array}$ & 231.28 & 208.88 & 2000 \\
\hline Turbidity, NTU & 29.60 & 19.50 & NA \\
\hline TSS, (mg/L) & 27.00 & 14.00 & 30 \\
\hline $\mathrm{DO},(\mathrm{mg} / \mathrm{L})$ & 5.01 & 5.16 & NA \\
\hline Nitrate, (mg/L) & 4.22 & 4.14 & NA \\
\hline Phosphate, (mg/L) & 0.63 & 0.54 & NA \\
\hline BOD, (mg/L) & 6.25 & 6.01 & 10 \\
\hline COD, (mg/L) & 10.05 & 8.88 & 10 \\
\hline TOC, (mg/L) & 3.50 & 1.66 & NA \\
\hline TPH, (mg/L) & 5.09 & 2.97 & 10 \\
\hline Iron, (mg/L) & 0.775 & 0.605 & 1.0 \\
\hline Zinc, mg/ & 0.750 & 0.655 & 1.0 \\
\hline Lead, (mg/L) & 0.031 & 0.024 & 0.05 \\
\hline Nickel, (mg/L) & 0.188 & 0.121 & NA \\
\hline Chromium, (mg/L) & 0.025 & 0.017 & 0.03 \\
\hline Cadmium, (mg/L) & 0.054 & 0.048 & NA \\
\hline Cobalt, (mg/L) & 0.011 & 0.008 & NA \\
\hline Mercury, (mg/L) & $<0.001$ & $<0.001$ & NA \\
\hline
\end{tabular}

Table 1: Baseline physicochemical parameters.

lowers cholesterol levels, because these mushrooms naturally contain lovastatin. Studies have shown they contain up to $2.8 \%$ lovastatin on a dry weight basis. Many fungal species have been extensively studied for their heavy metals removal efficiency [4]. P. ostreatus or commercially known as oyster mushroom is an edible fungus commonly found in Asian cuisine. Biosorbent of $P$. ostreatus is easily available from agricultural waste of oyster mushroom cultivation farm or from fermentation industry. Although different potential fungal biosorbents have been investigated, very little is known of the ability of $P$. ostreatus in heavy metals removal. The present study was undertaken to investigate the bioremoval potential of $P$. ostreatus in effluent obtained from Port Harcourt refinery Co. Ltd, a subsidiary of NNPC, Alesa, Eleme, Rivers State, Nigeria.

\section{Materials and Methods}

\section{Sample collection}

The white rot Fungi mushroom, $P$. ostreatus used was obtained from NDDC/RSUST/DIPLOMAT mushroom/spawn production and research centre of the Faculty of Agriculture Teaching and Research Campus, Rivers State University of Science and Technology, Nkpolu, Port Harcourt. A 10 liter container sterilized with $70 \%$ ethanol was used to collect the effluent from the refinery drains and taken to the laboratory for immediate analysis. The physiochemical parameters of the effluent were analysed to have an initial value on day zero. The substrates sawdust and rice bran were fermented and pasteurized using heat at NDDC/RSUST/DILOMAT mushroom/spawn production and research centre of the faculty of Agriculture Teaching and Research Campus, Rivers State University of Science and Technology, Nkpolu, Port Harcourt.

\section{Substrate for spawn preparation}

Guinea corn was used for spawn preparation. The spawn was bought at NDDC/RSUST/DILOMAT mushroom/spawn production and research centre of the Faculty of Agriculture Teaching and Research Campus, Rivers State University of Science and Technology, Nkpolu, Port Harcourt.

\section{Physiochemical characteristic of the effluent}

pH: pH was measured using APHA $4500 \mathrm{H}^{+}$(Electrode Method).

Temperature: The temperature reading of the sample was taken at site of collection using a thermometer (Orion, USA).

Biochemical Oxygen Demand (BOD): BOD was determined using the dilution method according to APHA 5210B [5].

Total Organic Carbon (TOC): TOC was determined according to APHA $5310 \mathrm{C}$

Total Petroleum Hydrocarbon (TPH): TPH was done determined using the ASTM D5765-95.

Phosphate concentration: Phosphate concentration was determined by Ascorbic acid method.

Nitrate concentration: Nitrate concentration was determined using the ASTM D3867.

Determination of the heavy metals in the sample: The heavy metals analyzed in the samples included the following, Lead, Chromium, Copper and Iron by means of an atomic absorption spectrophotometer [5].

\section{Experimental Design}

Five different treatment options were set up in and labeled A-E in a plastic container with cover. Flask A: Containing 1.6 liters of the original sample to monitor the natural process. It's the positive control. Flask B: Containing 1.6 liters of the filtered sample. It's the negative control. Flask C: Containing 1.6 liters of the effluent, seeded with spawn. Flask D: Containing 1.6 liters of the effluent seeded with spawn and fermented saw dust. Flask E: Containing 1.6 liters of the effluent, seeded with spawn, fermented saw dust and fermented rice bran. The samples were kept at room temperature for 60 days. Fifty millilitres $(50 \mathrm{ml})$ of each sample was used for analysis. The concentrations of the heavy metals were measured every 15 days. The concentrations of the above heavy metals in washed test effluent and the filtrate were determined respectively on the $60^{\text {th }}$ day using atomic absorption spectrophotometer.

\section{Statistical analysis}

Data from the different measurements were subjected to one way analysis of variance (ANOVA) using SPSS 20.

\section{Results}

\section{Baseline physicochemical parameters}

The baseline physicochemical parameters of the effluent are shown in Table 1. It was observed that the initial temperature of the effluent was $27.0^{\circ} \mathrm{C}$ with $\mathrm{pH}$ at 6.87 and differed from that of filtered effluent which was 26.90 at $\mathrm{pH}$ 7.05. There were variations in the physicochemical parameters, with filtered effluent showing lower levels.

\section{Heavy metals removal from the effluent}

Reactors A and B showed that there was a little reduction of iron, zinc, lead, nickel, chromium and cadmium from day 15 (Tables 2-7). There was a reduction in lead and nickel for treatment options C, D and $\mathrm{E}$. There was a significant reduction in the potential of all treatment options for the bioremoval of the heavy metals in day 15 . On day 30 , there was an impressive performance in the bioremoval of lead, zinc, nickel, chromium, cadmium from the effluent in options A, C, D, and $\mathrm{E}$ as shown in (Tables 3-7). On day 45, option $\mathrm{D}$ and $\mathrm{E}$ increases in 
Citation: Stanley HO, Ihennacho CM, Stanley CN (2017) Bioremoval of Heavy Metals from Effluent of Port Harcourt Refinery Using Pluerotus ostreatus. J Pet Environ Biotechnol 7: 324. doi: 10.4172/2157-7463.1000324

Page 3 of 4

bioremoval all the heavy metals present except iron. On day 60 , the mushroom adsorbed more of all the metals and their levels in the effluent were reduced to the nearest minimum. Increasing biosorption capacity and efficiency was observed at contact time between days 45 and 60.

\section{Effect of $\mathrm{pH}$ in the treatment of effluent}

It was found that as the $\mathrm{pH}$ increased from 6 to 9 as the biosorption capacity decreased. The highest percentage removal was observed at contact time day 60 when $\mathrm{pH}$ of the treatment option $\mathrm{C}$ was 7.12 with Iron $54.63 \%$, Zinc $95.40 \%$, Lead $95.24 \%$, Nickel $89.47 \%$. Chromium $94.00 \%$, and Cadmium 93.75\% respectively in treatment D when $\mathrm{pH}$ was 7.43 Iron $78.70 \%$, Zinc 99.82\%, Lead 93.33\%, Nickel 99.21\%. Chromium $94.00 \%$, and Cadmium $93.75 \%$ respectively were removed. For treatment E, at pH 7.63 Iron 80\%, Zinc 99\%, Lead 94\%, Nickel 99\%. Chromium 93\% and Cadmium 96\% respectively were removed (Tables 2-7).

\begin{tabular}{|c|c|c|c|c|c|}
\hline \multirow{2}{*}{ Day } & \multicolumn{5}{|c|}{ Treatment } \\
\cline { 2 - 6 } & A & B & C & D & E \\
\hline 0 & 0.00 & 0.00 & 0.00 & 0.00 & 0.00 \\
\hline 15 & 1.94 & 0.50 & 6.40 & 59.00 & 51.00 \\
\hline 30 & 5.81 & 0.90 & 5.92 & 11.23 & 18.50 \\
\hline 45 & 8.39 & 0.11 & 7.00 & 17.01 & 21.85 \\
\hline 60 & 8.65 & 0.17 & 54.63 & 78.74 & 80.11 \\
\hline
\end{tabular}

Table 2: Percentage decrease in iron.

\begin{tabular}{|c|c|c|c|c|c|}
\hline \multirow{2}{*}{ Day } & \multicolumn{5}{|c|}{ Treatment } \\
\cline { 2 - 6 } & A & B & C & D & E \\
\hline 0 & 0.00 & 0.00 & 0.00 & 0.00 & 0.00 \\
\hline 15 & 2.80 & 2.14 & 54.00 & 50.00 & 49.00 \\
\hline 30 & 6.53 & 6.30 & 41.99 & 64.44 & 72.69 \\
\hline 45 & 7.47 & 7.00 & 49.36 & 74.14 & 76.39 \\
\hline 60 & 17.47 & 17.25 & 95.40 & 99.82 & 99.82 \\
\hline
\end{tabular}

Table 3: Percentage decrease in zinc.

\begin{tabular}{|c|c|c|c|c|c|}
\hline \multirow{2}{*}{ Day } & \multicolumn{5}{|c|}{ Treatment } \\
\cline { 2 - 6 } & A & B & C & D & E \\
\hline 0 & 0.00 & 0.00 & 0.00 & 0.00 & 0.00 \\
\hline 15 & 3.23 & 8.33 & 2.00 & 2.00 & 2.00 \\
\hline 30 & 6.45 & 10.90 & 23.81 & 33.33 & 56.25 \\
\hline 45 & 22.58 & 30.60 & 38.10 & 53.33 & 93.75 \\
\hline 60 & 35.48 & 41.67 & 95.24 & 93.00 & 93.75 \\
\hline
\end{tabular}

Table 4: Percentage decrease in lead.

\begin{tabular}{|c|c|c|c|c|c|}
\hline \multirow{2}{*}{ Day } & \multicolumn{5}{|c|}{ Treatment } \\
\cline { 2 - 6 } & A & B & C & D & E \\
\hline 0 & 0.00 & 0.00 & 0.00 & 0.00 & 0.00 \\
\hline 15 & 3.19 & 9.10 & 13.00 & 11.00 & 11.00 \\
\hline 30 & 5.85 & 11.00 & 7.52 & 23.68 & 17.59 \\
\hline 45 & 75.00 & 15.70 & 27.07 & 55.26 & 64.81 \\
\hline 60 & 37.23 & 19.83 & 89.47 & 99.21 & 99.17 \\
\hline
\end{tabular}

Table 5: Percentage decrease in nickel.

\begin{tabular}{|c|c|c|c|c|c|}
\hline \multirow{2}{*}{ Day } & \multicolumn{5}{|c|}{ Treatment } \\
\cline { 2 - 6 } & A & B & C & D & E \\
\hline 0 & 0.00 & 0.00 & 0.00 & 0.00 & 0.00 \\
\hline 15 & 4.00 & 5.89 & 2.00 & 2.00 & 13.00 \\
\hline 30 & 4.00 & 9.20 & 33.33 & 46.67 & 38.46 \\
\hline 45 & 24.00 & 21.30 & 46.67 & 94.00 & 93.08 \\
\hline 60 & 32.00 & 29.41 & 94.00 & 94.00 & 93.08 \\
\hline
\end{tabular}

Table 6: Percentage decrease in chromium.

\begin{tabular}{|c|c|c|c|c|c|}
\hline \multirow{2}{*}{ Day } & \multicolumn{5}{|c|}{ Treatment } \\
\cline { 2 - 6 } & A & B & C & D & E \\
\hline 0 & 0.00 & 0.00 & 0.00 & 0.00 & 0.00 \\
\hline 15 & 5.60 & 4.17 & 3.00 & 2.00 & 2.00 \\
30 & 22.22 & 15.00 & 40.63 & 79.17 & 76.19 \\
\hline 45 & 31.48 & 30.10 & 53.13 & 91.67 & 95.71 \\
\hline 60 & 40.74 & 47.92 & 93.75 & 96.25 & 95.71 \\
\hline \multicolumn{7}{|c}{ Table 7: Percentage decrease in cadmium. } \\
\hline
\end{tabular}

\section{Effect of temperature on biosorption by $P$. ostreatus}

The effect of temperature during biosorption of iron, zinc, lead, nickel, chromium and cadmium was studied. Based on the results obtained, it was observed that the biosorption of metal ions decreased with increasing temperature from $25^{\circ} \mathrm{C}$ to $35^{\circ} \mathrm{C}$ (Tables 8-11).

\section{Discussion}

The physicochemical properties measured in the present study are Total Organic Carbon (TOC), Total Suspended Solid (TSS), Total Petroleum Hydrocarbons (TPH), Dissolved Oxygen (DO), BOD, pH, nitrate, turbidity, temperature and heavy metals such as iron, lead, zinc, nickel, chromium and cadmium. The $\mathrm{pH}$ values (6.87-7.05) fall within the DPR limit of 6.5-8.5 but the temperature values for all samples exceeded the DPR limit of $25^{\circ} \mathrm{C}$. The total concentration of heavy metals analyzed in this study did not give any cause for concern. This agrees with the report of Stigter [6]. Sufficient concentration of total organic carbon, nitrate and phosphate in the medium was able to sustain the growth of $P$. ostreatus in the effluent for the period of the study. Physiochemical properties of effluents favour the growth of the mushroom [7].

The metal removal efficiency of the various treatments showed variations. Treatment option A (positive control) which is the natural process showed the presence of all the metals- iron, zinc, lead, nickel, chromium and cadmium. Treatment option B (negative control) which is the filtered sample showed presence of some of the metals, an indication that not all the metals were eliminated by filtration. The activities in treatment option $\mathrm{E}$ demonstrated an excellent performance with a seemingly constant percentage removal for 60 days. The reduction may be due to the presence of sufficient nutrient in the

\begin{tabular}{|c|c|c|c|c|c|}
\hline Parameters & A & B & C & D & E \\
\hline $\mathrm{pH}$ & 7.17 & 6.40 & 5.60 & 5.53 & 6.59 \\
\hline Temp, $\left({ }^{\circ} \mathrm{C}\right)$ & 26.40 & 26.50 & 26.50 & 26.20 & 26.60 \\
\hline Iron, $(\mathrm{mg} / \mathrm{L})$ & 0.760 & 0.622 & 0.643 & 0.588 & 0.508 \\
\hline Zinc, $\mathrm{mg} /$ & 0.729 & 0.641 & 0.543 & 0.495 & 0.487 \\
\hline Lead, $(\mathrm{mg} / \mathrm{L})$ & 0.032 & 0.022 & 0.021 & 0.015 & 0.016 \\
\hline Nickel, $(\mathrm{mg} / \mathrm{L})$ & 0.182 & 0.124 & 0.133 & 0.114 & 0.108 \\
\hline Chromium, $(\mathrm{mg} / \mathrm{L})$ & 0.027 & 0.018 & 0.015 & 0.015 & 0.013 \\
\hline Cadmium, $(\mathrm{mg} / \mathrm{L})$ & 0.051 & 0.046 & 0.032 & 0.024 & 0.021 \\
\hline
\end{tabular}

Table 8: Physicochemical parameters of effluent on day 15.

\begin{tabular}{|c|c|c|c|c|c|}
\hline Parameters & A & B & C & D & E \\
\hline${ }_{\mathrm{P}} \mathrm{H}$ & 7.06 & 6.80 & 6.17 & 6.71 & 6.75 \\
\hline Temp, $\left({ }^{\circ} \mathrm{C}\right)$ & 26.50 & 26.00 & 26.80 & 26.40 & 26.20 \\
\hline Iron, $(\mathrm{mg} / \mathrm{L})$ & 0.73 & 0.675 & 0.61 & 0.52 & 0.41 \\
\hline Zinc, mg/ & 0.70 & 0.662 & 0.32 & 0.18 & 0.13 \\
\hline Lead, (mg/L) & 0.03 & 0.022 & 0.02 & 0.01 & 0.01 \\
\hline Nickel, (mg/L) & 0.18 & 0.120 & 0.12 & 0.09 & 0.09 \\
\hline Chromium, (mg/L) & 0.02 & 0.018 & 0.01 & 0.01 & 0.01 \\
\hline Cadmium, (mg/L) & 0.04 & 0.038 & 0.02 & 0.01 & 0.01 \\
\hline
\end{tabular}

Table 9: Physicochemical parameters of effluent on day 30. 


\begin{tabular}{|c|c|c|c|c|c|}
\hline Parameters & A & B & C & D & E \\
\hline${ }_{\mathrm{P}} \mathrm{H}$ & 7.11 & 6.44 & 6.34 & 6.97 & 7.28 \\
\hline Temp, $\left({ }^{\circ} \mathrm{C}\right)$ & 26.90 & 26.90 & 27.00 & 26.90 & 27.10 \\
\hline Iron, $(\mathrm{mg} / \mathrm{L})$ & 0.71 & 0.61 & 0.60 & 0.49 & 0.40 \\
\hline Zinc, mg/ & 0.69 & 0.54 & 0.28 & 0.13 & 0.12 \\
\hline Lead, (mg/L) & 0.02 & 0.01 & 0.01 & 0.01 & $<0.002$ \\
\hline Nickel, (mg/L) & 0.15 & 0.10 & 0.10 & 0.05 & 0.04 \\
\hline Chromium, (mg/L) & 0.02 & 0.01 & 0.01 & $<0.001$ & $<0.001$ \\
\hline Cadmium, (mg/L) & 0.04 & 0.03 & 0.02 & 0.002 & $<0.001$ \\
\hline
\end{tabular}

Table 10: Physicochemical parameters of effluent on day zero 45

\begin{tabular}{|c|c|c|c|c|c|}
\hline Parameters & A & B & C & D & E \\
\hline${ }^{H} \mathrm{H}$ & 7.84 & 6.82 & 7.12 & 7.43 & 7.63 \\
\hline Temp, $\left({ }^{\circ} \mathrm{C}\right)$ & 27.20 & 26.90 & 27.00 & 27.30 & 26.80 \\
\hline Iron, $(\mathrm{mg} / \mathrm{L})$ & 0.71 & 0.61 & 0.31 & 0.13 & 0.10 \\
\hline Zinc, $\mathrm{mg} /$ & 0.62 & 0.54 & 0.03 & $<0.001$ & $<0.001$ \\
\hline Lead, $(\mathrm{mg} / \mathrm{L})$ & 0.02 & 0.01 & $<0.002$ & $<0.002$ & $<0.002$ \\
\hline Nickel, $(\mathrm{mg} / \mathrm{L})$ & 0.12 & 0.10 & 0.01 & $<0.001$ & $<0.001$ \\
\hline Chromium, $(\mathrm{mg} / \mathrm{L})$ & 0.01 & 0.01 & $<0.001$ & $<0.001$ & $<0.001$ \\
\hline Cadmium, $(\mathrm{mg} / \mathrm{L})$ & 0.03 & 0.03 & 0.002 & $<0.001$ & $<0.001$ \\
\hline
\end{tabular}

Table 11: Physicochemical parameters of effluent on day 60.

effluent. Treatment option $\mathrm{C}$ and $\mathrm{D}$ also demonstrated good reduction performance due to less substrate compared to treatment option E. The decrease from day 15 may be as a result of the presence of some intermediate metabolic products that might have altered the condition of the medium. The production of appropriate enzyme system and increase in cell population may be responsible for increase as seen from day 30. Fungi have excellent biosorbent capabilty due to their fast growth rate, minimal nutrient requirement as well as large biomass production. The composition of the fungal cell wall and the filamentous morphology of fungi may be an added advantage. The reduction from day 60 of the growth rate of the mushroom may be as a result of the production of inhibiting metabolites, insufficient binding sites for the metals, loss of nutrient and probably cell death. P. ostreatus showed better bioremoval with zinc, lead, nickel, chromium and cadmium than iron.

$\mathrm{pH}$ affects biosorption of metal ions. Arbanah [8] reported that metal ions removal increased when $\mathrm{pH}$ is greater than 4 . At $\mathrm{pH}$ 7.6, the removal of the metals under study is faster because the proton competition between the metals and $\mathrm{H}_{3} \mathrm{O}^{+}$are lower thus increase the potential of the metals binding to $P$. ostreatus active sites. At this time, the affinity of the P. ostreatus surface for the metals also increased. At $\mathrm{pH}$ higher than 3 the biosorbent possess more functional group carrying a net negative charge, which tends to repulse the anions from aqueous solution. Based on obtained results, the optimum $\mathrm{pH}$ in biosorption process were found to be 7.5 .

Fungi species have been reported to show a greater affinity to bioadsorb heavy metals under experimental condition. Onianwah [9] reported the bioremoval of heavy metals by Aspergillus niger, Rhizopus stolonifer and a consortium of the fungi with $69.4 \%, 2.9 \%, 53.3 \%$, $48.1 \%$ and $49 \%$ of Cadmium; $47.1 \%, 1.0 \%, 38.2 \%, 52.7 \%$ and $35.4 \%$ of Nickel; $63.7 \%, 1.2 \%, 48.6 \%, 49.8 \%$ and $72.4 \%$ of Zinc respectively. The mushroom $P$. ostreatus exhibited excellent biosorbent efficiency for Iron 80\%, Zinc 99\%, Lead 94\%, Nickel 99\%. Chromium 93\%, and Cadmium 96\% respectively, making a better candidate for bio-adsorption of heavy metals. Results revealed that iron is easily available to most organisms than zinc, lead, nickel, chromium and cadmium. The removal of these metals by mushroom and bioadsorption may be as a result of production of acids like citric, oxalic, fumaric, lactic, malic acids etc. which may chelate toxic metals resulting in the formation of metal organic molecules [1].

Since metals can attach to the cell wall by week van der waals force, it thus makes washing off easy or reaction reversible. The ability of the mushroom to biorecover these metals from the effluent makes them recommended for use in remediating heavy metal impacted environment. The removal ability of the fungi $P$. ostreatus could be attributed to its large surface and high chitin and chitosan content of the cell walls, which allows for greater binding surface and functional groups which form complexes with the metals. The spawn can grow easily in bulk on low cost substrates (sawdust and rice bran) which are by-products of Agricultural industries.

The accumulation of metals in the tissues of mushrooms affects their viability and edibility [10]. Some of the metals like iron are essential for normal or healthy growth of plants and animals. The mushroom $P$. ostreatus is an edible one and chances are they will find their way into the human diet. The mushroom is treated as a vegetable and there are maximum permissible limits for these metals or elements in vegetables. Care must be taken therefore that mushroom used for bioremediation do not end up in the food chain.

\section{Conclusion}

This study showed that Pleurotus ostreatus has great ability to bioremove heavy metals from petroleum refinery effluent. Removal of heavy metals by $P$. ostreatus biosorbent is in-line with the alternative sustainable technology development for waste water purification system. It is a veritable tool in serving the environment. This study showed that the application of fungi as metallic bio-sorbents for polluted sites is possible. There was removal of heavy metals from the effluent by the fungus reducing the concentrations of some of the metals below accepted limits for normal effluents. It is therefore suggested that soils remediated with white-rot fungi be augmented with micronutrients for plant's sustenance. Spawn in contaminated effluent can accumulate heavy metals to toxic levels and this can affect their edibility.

\section{References}

1. Volesky B (2007) Bio-removal and me. Water Research. 41: 4017-4029.

2. Kataizyna C (2005) Bioremoval of $\mathrm{Cr}$ (III) ions by egg shells. J Hazard Mater 121: $167-173$

3. Norton L, Baskaran K, Mckenzie ST (2004) Bioremoval of Zinc from aqueous solutions using biosolids. AAV Environ. Res. 8: 629-635.

4. Wang J, Chen C (2009) Biosorbents for heavy metals removal and their future. Biotechnol Adv. 27: 195-226.

5. APHA (2012) Information booklet on analytical procedure.

6. Stigter JB, De Haan HPM, Guicherit R, Dekkers CPA, Daane ML (2000) Determination of cadmium, zinc, copper, chromium and arsenic in crude oil cargoes. Environ. Pollut. 107: 451-464.

7. Mashitah MD, Yus Y, Bhatia S (2008) Bioremoval of Cadium (II) ions by immobilized cells of pycnoporus sanguineus from aqueous solution. Bioresource Technology 99: 4742-4748.

8. Arbanah M, Miradatul NMR, Ku Halim KH (2013) Utilization of Pleurotus ostreatus in the removal of $\mathrm{Cr}(\mathrm{VI})$ from Chemical laboratory waste. International Refereed Journal of Engineering and Science. 2: 29-39.

9. Onianwah IF, Stanley HO, Stanley CN (2013) Bioremoval of cadmium, mercury nickel and zinc from leachate sample collected from refuse dump on Obir Ikwerre/air port link road using living cells of Aspegillus niger and Rhizopus stolonifer. International Research Journal of Environment Sciences 2: 1-8.

10. Tumin ND, Chuah AL, Zawani Z, Rashid SA (2008) Adsorption of copper from aqueous solution by elais guineensis kernel activated carbon. J Eng Sci Tech 3: 180-189. 